\title{
Diagnosis and management of eosinophilic granuloma of the jaw: a case report
}

\author{
Diagnóstico e tratamento do granuloma eosinofilico \\ de mandíbula: relato de caso
}

\author{
Marcos Vinícius Mendes DANTAS ${ }^{1}$ iD 0000-0002-4427-5941 \\ Paloma Beatriz Rosa Nunes de SOUZA ${ }^{1}$ iD 0000-0002-1052-9042 \\ Marisa Aparecida Cabrini GABRIELLI' iD 0000-0002-7147-1438
}

\begin{abstract}
The eosinophilic granuloma is the most common form of the Langherans' cell histiocytosis. In the majority of cases it is represented by a unilocular osteolytic lesion which can occur in adults and children. It is an intraosseous destructive lesion characterized by the presence of vast numbers of eosinophils and histiocytes. It can be localized or multifocal. The tumor is more prevalent in the first two decades of life and tends to affect mandibular body and angle. Most frequent signs and symptoms are pain, swelling, ulceration, gingival necrosis, alveolar bone destruction with mobility and loss of teeth. Therapeutic interventions for this pathology are surgical curettage, local radiotherapy and chemotherapy. This article presents the case of a 9-year old patient who came in for treatment with facial swelling, pain, tooth mobility and intraoral ulcer in the vestibular sulcus of the right mandibular angle region. Imaging and incisional biopsy were obtained. After the histopathological examination confirmed the diagnosis of eosinophilic granuloma, the lesion was removed by curettage and a reconstruction titanium plate was inserted to avoid a pathological fracture. After 14 years of followup no recurrence was found and mandibular growth was not impaired. A discussion about this type of tumor is presented, based on the current literature.
\end{abstract}

Indexing terms: Curettage. Eosinophilic granuloma. Langerhans cell histiocytosis,

\section{RESUMO}

O granuloma eosinofilico é a forma mais comum da Histiocitose das células de Langerhans e que na maioria das vezes é representada por uma lesão osteolitica unilocular podendo acometer crianças e adultos. Trata-se de uma lesão óssea destrutiva caracterizada por presença de um vasto número de eosinófilos e histiócitos, podendo ser localizada ou multifocal. Apresenta maior incidência nas duas primeiras décadas de vida e tende a afetar as regiões de corpo e ângulo mandibular. A sintomatologia e sinais clínicos mais frequentes são dor, edema, ulceração, necrose da gengiva, destruição do osso alveolar, consequentemente mobilidade e perda dentária. As medidas terapêuticas para essa patologia são a curetagem cirúrgica, a irradiação local e a quimioterapia. O objetivo deste trabalho é apresentar um caso clínico de granuloma eosinofílico ocorrido em criança de 9 anos de idade que procurou tratamento devido a um aumento volumétrico em face, mobilidade dentária, queixa dolorosa e presença de úlcera intra-oral no fundo de sulco vestibular da região do ângulo mandibular, lado direito. Exames de imagens bem como biópsia incisional foram realizados. Após o resultado

$\operatorname{rr}$

1 Universidade Estadual Paulista, Faculdade de Odontologia de Araraquara, Departamento de Diagnóstico e Cirurgia. Rua Humaitá, 1680, 14801-385, Araraquara, SP, Brasil. Correspondência para / Correspondence to: MVM DANTAS. E-mail: <mvmdantas@hotmail.com>.

$\cdots$

How to cite this article

MVM Dantas, PBRN Souza, MAC Gabrielli. I. Diagnosis and management of eosinophilic granuloma of the jaw: a case report. RGO, Rev Gaúch Odontol 2019;67:e20190029. http://dx.doi.org/10.1590/1981-86372019000293576 
histopatológico da biópsia com confirmação do diagnóstico, a paciente foi submetida ao tratamento cirúrgico por meio de curetagem e instalada placa de reconstrução para evitar fratura patológica. No momento, apresenta acompanhamento pós-operatório de 14 anos sem recidiva da lesão ou comprometimento do crescimento mandibular. Além disso, será apresentada uma discussão do tipo de lesão com base na literatura atual.

Termos de indexação: Curetagem. Granuloma eosinofilico. Histiocitose.

\section{INTRODUCTION}

Eosinophilic (monostotic or polystotic) granuloma $(E G)$ is the mildest form of the disease of Langerhans' cell Histiocytosis [1]. It is a bone lesion that may present in a solitary or multiple forms. Approximately $50 \%$ of cases develop in the first two decades of life and between 10 and $20 \%$ occur in the mandibular bone [2-6].

The most frequent signs and symptoms of this pathology are pain, edema, ulceration, gingival necrosis, destruction of the alveolar bone with mobility and loss of teeth $[3,6,7]$. Depending on the bone destruction of the maxillae, it may lead to pathological fractures $[3,7]$.

Radiographically, the lesions present as radiolucent areas accompanied by a perforating aspect without cortical margin, and become more evident when the alveolar cortical bone is destroyed. Extensive involvement of the alveolar bone may result in the appearance of teeth "floating in the air" $[1,6,8]$. In these cases teeth may be observed with the presence of mobility and deep periodontal pockets, mucosa with ulcerative or proliferative lesions, with erythema and severe tendency to bleeding on probing [7]. These clinical and radiographic characteristics resemble those of aggressive periodontal diseases $[1,2,4,5]$, and therefore, it is important to perform differential diagnosis by means of specific clinical findings, evolution of the pathology and biopsy for histopathological exam.

Acute dissemination of this pathology is more commonly found in children, with involvement of the skin, mucosa and bone. In addition to the maxillae, the cranial bones may be affected, particularly the parietal, spinal column and pelves. Furthermore, it may present the development of lesions in viscera such as the liver, spleen and lungs. When there is involvement of these organs, death occurs in over $50 \%$ of the cases [9].

The chronic form of this pathology is associated with the presence of a triad of with their own characteristics, which include osteolytic lesions, exophthalmia and insipid diabetes $[5,7,9]$.

The therapeutic options for the treatment of EG are surgical removal by means of curettage, radiotherapy in low doses, chemotherapy, intralesional injection of steroids for reduction in size of the lesion followed by curettage, and depending on the case, there are reports of spontaneous resolution of the lesion $[3,7,8]$. Moreover, for confirmation of the diagnosis, incisional biopsy and histopathological analysis [6] are necessary, because from the clinical characteristics of the lesion, it may present differential diagnosis from other pathologies, such as osteomyelitis, carcinoma, sarcoma, lymphoma, Paget's disease, multiple myeloma and Papillon-Lefèvre Syndrome $[3,6,8]$.

Based on these considerations, the aim of this article was to present a clinical case of EG affecting the mandible of a 9-year-old patient, whose treatment was performed by surgical curettage, and who received postoperative follow-up for 14 years. Furthermore, discussion of the lesion based on the literature was presented.

\section{CASE REPORT}

The patient presented to an Oral and Maxillofacial Surgery Service of the Dental School - UNESP Araraquara with complaint about edema in the regions of the right mandibular angle, with the evolution of an increase in volume having been observed in the last fifteen days. On extra-oral physical exam (figure 1A), facial asymmetry was noted due to the increase in volume in the right mandibular angle region, with a soft consistency, absence of hyperemia at the site and/or presence of fistula that could be a suspected tooth abscess. The patient reported pain on palpation and palpable right submandibular lymph node. On intra-oral physical exam (figure 1B), erythematous mucosa, ulcerated in the area of the right retromolar trigone and absence of purulent exudation were observed.

The imaging exams showed a radiolucent lesion delimited by sclerotic margins in the right mandibular angle region, extending up to the permanent first molar and base of the mandible (figure 2A). The computed tomography images showed expansion of the cortical bones in both the vestibular and lingual areas, and with bone lysis, which extended from the mandibular base up to the alveolar bone (figure $2 \mathrm{~B}$ ), involving the first molar and second molar tooth germs of the region (figure $2 \mathrm{~A}$ ). 

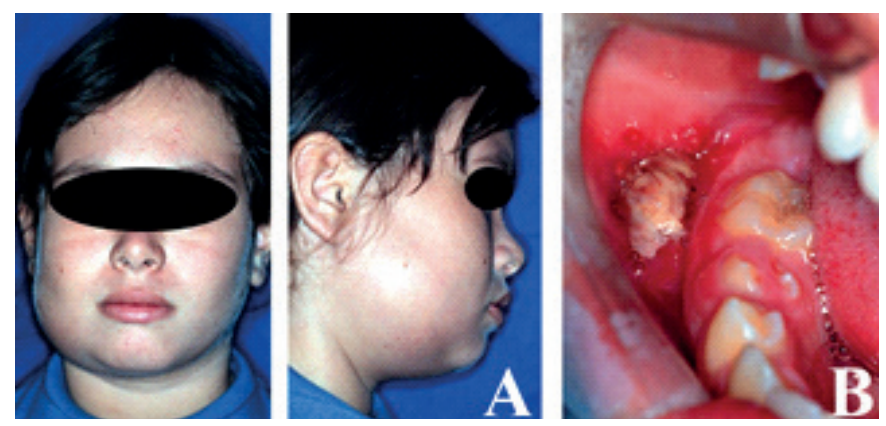

Figure 1. Initial of extra (A) and intra-oral(B) physical exams.
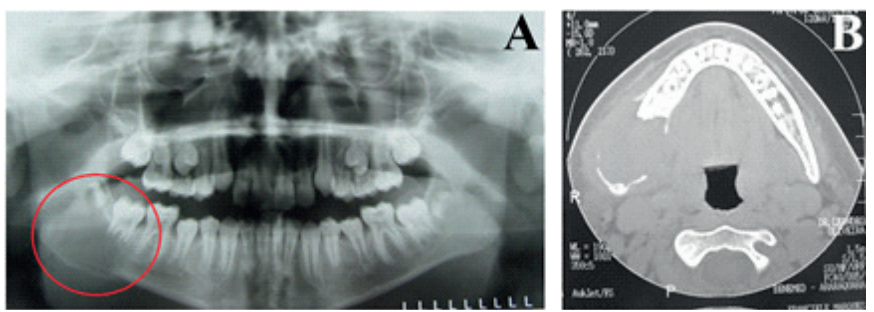

Figure 2. Pre-operative Panoramic Radiograph (A- circle highlights well defined radiolucent area) and Tomography (B).

From the clinical and imaging findings, the suggested diagnoses were 1. ameloblastoma, 2. eosinophilic granuloma, 3. keratocyst, 4. lymphoma and 5.osteomyelitis. The tendency to suspect these lesions was justified, in general, by the increase in volume with cortical bone expansion and radiolucent area characteristic of bone tissue destruction. Furthermore, in the case of keratocyst and ameloblastoma, there was involvement of the tooth germ and osteomyelitis due to the presence of ulceration in the mucosa.

The patient was submitted to incisional biopsy in an outpatient environment. The mandibular bone in the region of the lesion had a porous aspect with bone cavities presenting yellow colored, softened tissue, and sometimes liquefied within them. Both tissues of the lesion - the external cortical bone and tissue within the cavity were submitted to histopathological analysis. The result of analysis predominantly showed the presence of pale colored Langerhans' histiocytes with heterogeneous and cleaved nuclei, in addition to numerous eosinophils, determining the diagnosis of Eosinophilic Granuloma, with confirmation by means of immunohistochemistry.

Thus, the patient was submitted to tomographic exam of the abdomen, radiographs of the thorax, cranium and pelves, as well as scintigraphy to eliminate the presence of lesions in other organs.

After determining that the only EG lesion present was that in the region of the mandibular angle and body, the patient was submitted to surgical intervention under general anesthesia for excision of the lesion together with teeth 47 and 48 , with the intention of maintaining the bony base that was preserved. Due to the fragility and great chance of mandibular fracture, after excision of the lesion, a $2.4 \mathrm{~mm}$ system reconstruction plate was fixated to this mandibular segment, followed by scarification by means of a bur throughout the extension of the localization of the lesion. Simultaneously the inferior alveolar canal neurovascular bundle was preserved (figure 3). Sutures were performed by submandibular planes of access, and the alveoli where the molar teeth were removed were also occluded by sutures.

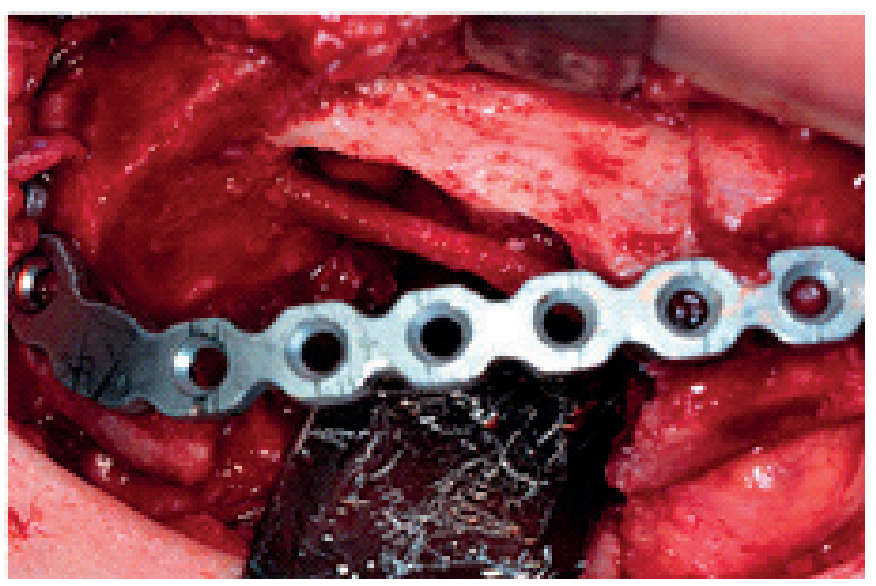

Figure 3. Transoperative image showing preservation of inferior alveolar nerve and fixation of reconstruction plate.

Post-operative follow-up was conducted by means for consultations with periodic returns. Immediately after discharge from hospital the patient was re-evaluated at time intervals of $07,15,30$ and 45 days. From this time onwards, until a year post-operatively was completed, follow-up was conducted every 3 months, and after this, annually. During the entire period of follow-up until the present time, in which the patient has completed 14 postoperative years, no recurrence of the lesion was observed, as shown in figures $4 \mathrm{~A}$ and $4 \mathrm{~B}$. In the radiographic images of the post-operative time intervals of 7 and 14 years (figures $5 \mathrm{~A}$ and $5 \mathrm{~B}$ ) there was evidence of adequate 

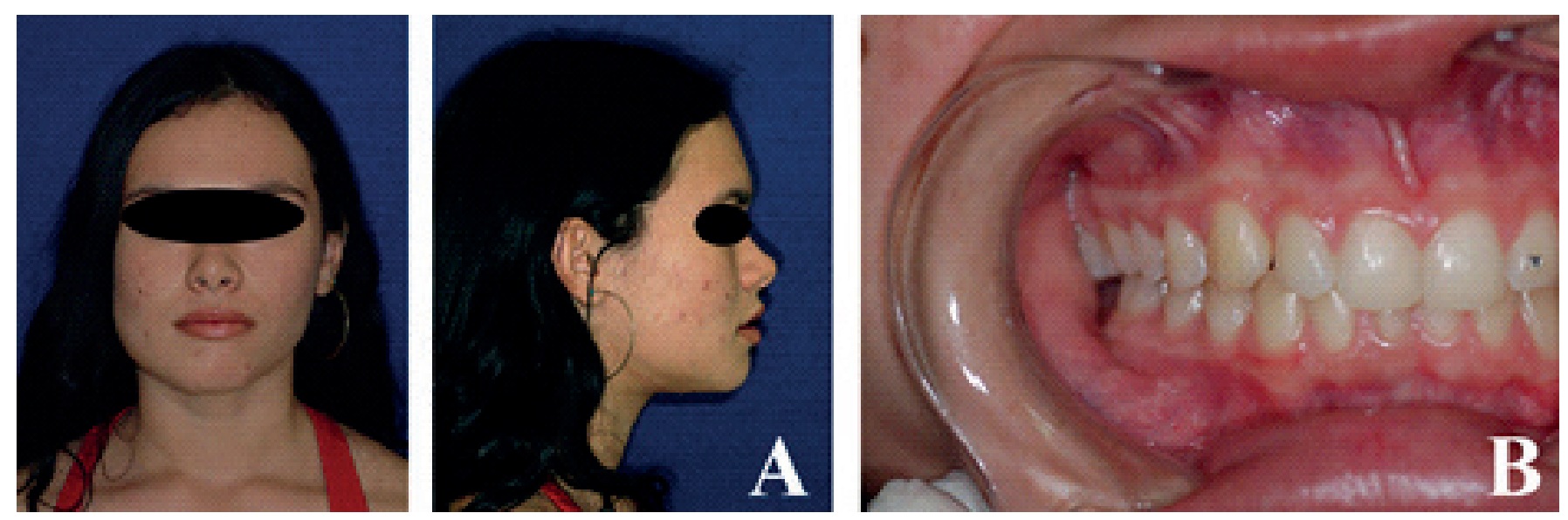

Figure 4. Images of extra $(A)$ and intra-oral(B) Clinical exams in 7 years of follow-up.

mandibular growth and absence of recurrence of the lesion. In addition, throughout the course of the post-operative period there was bone formation partially filling the space previously occupied by the mandibular lesion, allowing continuity of bone in the mandible.

The fixation material is still present, in spite of its removal having been proposed. The patient and her
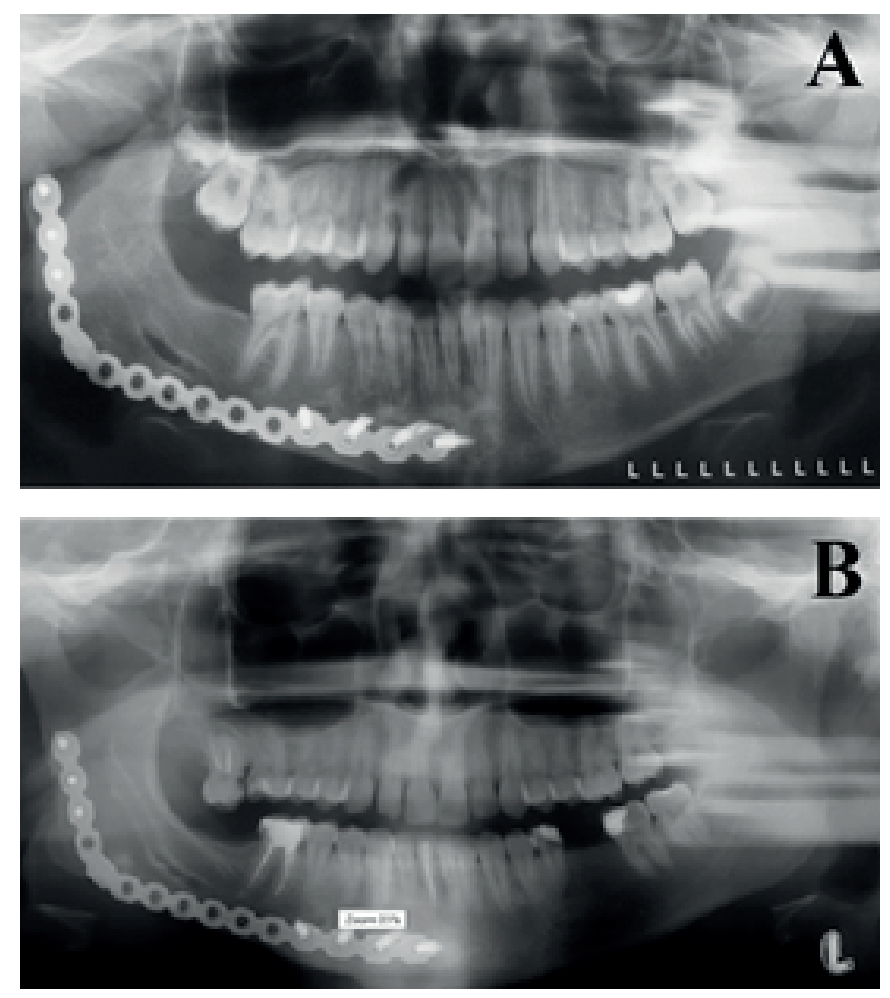

Figure 5. Postoperative panoramic radiographs of $7(A)$ and showing preservation of inferior alveolar nerve and (B)14 years without signs of recurrence. guardians did not agree to another surgical procedure for removal of the material.

\section{DISCUSSION}

EG is the most common presentation and is responsible for $50 \%$ to $70 \%$ of cases of Langerhans' cell Histiocytosis, more frequently occurring as a solitary osteolytic lesion, particularly in children and young adults, and is most frequent in the first decade of life $[3,5,7]$ which corroborates the findings of the present case. According to Atarbashi Moghadam et al. [4], Langerhans' cell Histiocytosis, is a disease of unknown pathogenesis, considered rare, with a prevalence of lower than $1 \%$ in the population studied between 1992 and 2012. In a recent review of the literature, Guruprasad \& Chauhan et al. [3] reported that around $76 \%$ of lesions of the maxillae occur in the mandible, with over $96 \%$ of the cases involving the mandibular ramus and body, facts that were considerably coincident with those of the case described.

The clinical and radiographic aspects of EG are very similar to those of other lesions, particularly chronic inflammatory lesion, odontogenic cyst, osteomyelitis, lymphoma, ameloblastoma and aneurysmal bone cyst $[3,6,10]$. In the case presented, some diagnostic hypotheses were suggested based on the history, clinical and radiographic findings, among them osteomyelitis by the evidence of bone resorption and presence of lesion in the mucosa; lymphoma, due to the complaint of pain and aspect of bone destruction with sclerotic margins. However, there was no history of weight loss, lymphadenopathy or 
splenomegaly. Ameloblastoma was one of the diagnostic hypotheses due to the presence of bone destruction and cortical expansions. In addition, a rare hypothesis - squamous cell carcinoma - was suggested by the presence of ulcer in the dental alveolar region, however, the patient's age was uncommon for this tumor.

From the radiographic point of view, in EG the presence of bone resorption with sclerotic margins with oval or rounded shape is frequent. The area of bone lysis is filled with softened, light brown colored tissue that becomes fibrous and grayish colored with time [6]. This characteristic of softened tissue with a coloring tending towards brown, was the same as the type described and found within the lesion of the clinical case presented. However, the definitive diagnosis needs to be determined by correlation of the clinical, imaging findings and histological characteristics [3,6].

Histologically, the main characteristics of the lesion were a histiocytic infiltrate, predominantly of a Langerhans' clonal proliferation, pathological cells that resembled tissue macrophages, typical Langerhans' dendritic cells on the skin. Typically the histiocytic cells have folded nuclei. Langerhans' cell infiltrate is accompanied by a variable quantity of giant cells similar to osteoclasts and eosinophils that are not necessarily mandatory for diagnosis. Moreover, polymorphonuclear lymphocytes, macrophages and a variable quantity of necrosis could also be present [3].

Thus, identification of Langerhans' lesional cells is necessary for confirming the diagnosis. As these cells cannot be differentiated from other histiocytes by routine histological staining, additional methods are necessary for diagnosis. Electron microscopy and immunohistochemical procedures are used to visualize cytoplasmic structures in the form of rods called Birbeck granules that belong to the Langerhans' cells [3]. For this reason, in addition to electron microscopy, immunohistochemistry was performed for differentiation of the Langerhans' cells, and diagnostic confirmation of the case presented. In immunohistochemistry, the protein markers S-100 and CD1-a are frequently used, which help with differentiation from other histiocytic processes.

Treatment is variable, depending on the presentation of this pathology. Spontaneous repair may have a favorable prognosis or may disseminate and change the function of vital organs with fatal consequences $[9,11]$. Normally, this is indicated for simple lesions that have not promoted asymmetry or bone discontinuity. A corticosteroid injection into the EG is another treatment option, and is preferably indicated for solitary lesions of a moderate size11, however the treatment by means of corticotherapy for EG is still without elucidation about the action of this medication.

Chemotherapy is indicated for cases of Langerhans' cell histiocytosis involving multiple organs and/or multiple bone lesions associated with lymphadenopathies. These chemotherapeutic drugs are used for chemotherapy, immuno-modulator and cytostatic drug (pharmacotherapy) treatments or an association of these. Low doses of radiotherapy may be applied in cases of lesions in areas with that are difficult to access surgically.

Surgical treatment is still the treatment of choice for EG [4]. The possibility of performing surgery in the case presented made this procedure the first option, in accordance with the classification presented by Bartnick et al.[13] in which stagings I and II, which involve bone or soft tissues, the treatment of choice is only surgical. This type of treatment was performed because it concerned a single lesion, with a large area of bone destruction, in which asymmetry of the mandibular bone was present, and by the absence of involvement of multiple organs.

The prognosis of treatment for EG is generally favorable for localized lesions. There is no literary description of malignant transformation. In rare circumstances, the solitary lesion may recur and result in death $[3,9]$. Therefore, a long follow-up time is imperative, and this fact justified the follow-up of 14 years of this clinical case.

\section{CONCLUSION}

Therefore, we were able to conclude, in general agreement with the literature $[3,7]$, that eosinophilic granuloma has the potential for bone destruction; it is necessary to establish the differential diagnosis by means of biopsy; its incidence is higher in the first decades of life; and surgical excision in the present case was shown to be adequate treatment. However, it is important to evaluate the possibility of advanced staging and with compromise of other organs which would require coadjuvant procedures.

\section{Collaborators}

MVM DANTAS, PBRN SOUZA and MAC GABRIELLI, did the surgical treatment and the follow-up of the patient. MVM DANTAS and MAC GABRIELLI, led the writing. 


\section{REFERENCES}

1. Lee $B D$, Lee $W$, Lee J, Son HJ. Eosinophilic granuloma in the anterior mandible mimicking radicular cyst. Imaging Sci Dent. 2013; 43(2): 117-122. http://dx.doi.org/10.5624/isd. 2013.43.2.117

2. Rezvani G, Dehghani Nazhvani A. Eosinophilic granuloma: report of a misconstrued case. J Dent Shiraz Univ Med Scien. 2012;13(14):181-183.

3. Guruprasad Y, Chauhan DS. Solitary. Eosinophilic granuloma of mandibular condyle. Literature review and report of a rare case. J Maxillofac Oral Surg. 2015;14(1):209-214. http://dx. doi.org/10.1007/s12663-012-0438-7

4. Atarbashi Moghadam S, Lotfi A, Piroozhashemi B, Mokhtari $S$. A retrospective analysis of oral langerhans cell histiocytosis in an iranian population: a 20-year evaluation. J Dent (Shiraz). 2015; 16(3 Suppl):274-277.

5. Ramos-Gutiérrez E, Alejo-González F, Ruiz-Rodríguez S, Garrocho-Rangel JA, Pozos-Guillén A. Langerhans cell histiocytosis: current concepts in dentistry and case report. J Clin Exp Dent. 2016; 8(1): e102-8. http://dx.doi.org/10.4317/ jced. 52498

6. Sherwani RK, Akhtar K, Qadri S, Ray PS. Eosinophilic granuloma of the mandible: a diagnostic dilemma. BMJ Case Rep. 2014;2014. pii: bcr2013200274. http://dx.doi.org/10. 1136/bcr-2013-200274.

7. Kannan K, Alwithanani N, Salama M, Kumar M, Uthappa R, Ahamed M. Eosinophilic granuloma in jaw bone: a pare pediatric case report. Ethiop J Health Sci. 2016;26(5): 487-490. http://dx.doi.org/10.4314/ejhs.v26i5.11
8. Raviraj J, Venkata S, Shaik S, Kodadala A, Kakarla P. Multifocal eosinophilic granuloma of jaws and skull with classical and unusual radiographic/imaging findings. J Clin Diagn Res. 2017;11(1): ZD09-ZD11. http://dx.doi.org/10.7860/JCDR/2017/ 23732.9154

9. Plona GA, Wiltz M, Kelsch R. Case Report: spontaneous resolution of an eosinophilic granuloma of the mandible following open biopsy. Oral Surg Oral Med Oral Pathol Oral Radiol. 2016;122:60-63. http://dx.doi.org/10.1016/j.0000.2015. 11.008

10. Fonseca N, Saikrishna D. Eosinophilic granuloma of mandible: a report of two cases. J Orofac Res. 2014;4(4):234-238.

11. Anjos PML, Silveira MM, Assis SLF, Filho FW. Eosinophilic granuloma in the jaws. Oral Surg Oral Med Oral Pathol Oral Radiol Endod. 2007;104(6):e47-51. http://dx.doi.org/10.10 16/j.tripleo.2007.07.006

12. Sang-Hwa L, Hyun-Joong $Y$. Intralesional infiltration of corticosteroids in the treatment of localized Langerhans cell histiocytosis of the mandible: report of two cases. Oral Surg Oral Med Oral Pathol Oral Radiol Endod. 2013;116(4):e255-60. http://dx.doi.org/10.1016/j.0000.2011.11.035

13. Bartnick A, Friedrich RE, Roeser K, Schmelzle R. Oral Langerhans cell histiocytosis. J Craniomaxillofac Surg. 2002;30(2):91-96. http://dx.doi.org/10.1054 / jcms.2001.0271

Received on: 31/1/2018 Final version resubmitted on: 2/4/2018 Approved on: 3/5/2018 